\title{
EVALUATION OF DYNAMICS OF ECONOMIC DEVELOPMENT IN POLISH AND LITHUANIAN REGIONS
}

\author{
Marek LISIŃSKI (D) ${ }^{1}$, Arūnas AUGUSTINAITIS² ${ }^{2}$ Lukasz NAZARKO (D ${ }^{*}$, \\ Sabina RATAJCZAK (D) 4 \\ ${ }_{1,4}$ WSB University, Dąbrowa Górnicza, Poland \\ ${ }^{2}$ Kazimieras Simonavičius University, Vilnius, Lithuania \\ ${ }^{3}$ Faculty of Engineering Management, Bialystok University of Technology, Bialystok, Poland
}

Received 23 January 2020; accepted 15 April 2020

\begin{abstract}
Regional policy of the countries - reducing disparities between economic development of the regions - has been, is and will continue to be the focus of policy makers' attention, therefore it is important to assess regional conditions qualitatively and to spot the differences in the change of these condition. This would be the basis for developing targeted strategies for further regional development. The process of regional economic development may be assessed quantitatively and qualitatively. The integrated mean of the statistical indicators reflects the dynamics of development. The paper's objective is to develop an aggregate indicator of development dynamics and to quantify the dynamics of the economic development of the Polish and Lithuanian regions. The employed methodological approach is based on the authors' definition of the mean of regional economic development equilibrium. The analysis of the statistical characteristics of the indicators of three regions of Poland and Lithuania has shown that the dynamics of economic development in the regions of both countries is similar. On the other hand, Poland is characterized by a more intensive development, while the development of Lithuanian regions is more levelled.
\end{abstract}

Keywords: regions, economic development, gross domestic product per capita, dynamics, Lithuania, Poland.

JEL Classification: N10, O11, O32, R11.

\section{Introduction}

The importance of regional development is widely recognised and discussed nowadays. It is manifested in three essential aspects - economic, social and environmental. The economic development of the regions is important because in the country as a whole, it is primarily the regions that create economic prosperity. On the other hand, we are faced with a situation where, historically (or for other reasons), some regions have developed large centres

${ }^{\star}$ Corresponding author. E-mail: l.nazarko@pb.edu.pl 
with a well-developed industry. This is, for example, the region of the country where the capital is located; or in whose territory there is a sea port and so on. All these circumstances presuppose unequal conditions for their development. This results in significant differences in development over the time. Another rather relevant social aspect, namely, regional development is closely linked to them. Uneven economic development increases social tensions not only in the regions but also in the country as a whole. It manifests itself in negative processes such as external and internal emigration, unemployment, rising crime, falling birth rates, and so on. Besides, the region's export opportunities and hence its competitiveness are diminishing.

Uneven regional development gives rise to another problem - environmental crisis, as regions lagging behind in their economic development are less able to deal with it. That is regional policy receives special attention. Its main objective is to reduce regional disparities in economic and social development. Regional development strategies for the country are being developed to achieve this. Their implementation depends on many circumstances. One of the key conditions for the successful implementation of the strategy is the ability to quantify the current regional development situation at the desired time span.

Based on the regional development studies conducted in the country in recent years, two sides of the development process can be distinguished: quantitative and qualitative (Ginevičius et al., 2015, 2018). The first one reflects upon the scale and nature of regional development changes over the period under review, and the second reflects changes in the structure of the development process. Both sides of this development integrate into the category of development dynamics.

Countries are paying increasing attention to regional policy and to various factors influencing regional development (Chodakowska \& Nazarko, 2017; Godlewska-Majkowska et al., 2016; Nazarko et al., 2017) with special focus on technology (Halicka, 2017; Nazarko, 2017), innovation (Nazarko \& Melnikas 2019) and digitalization (Turovets \& Vishnevskiy, 2019; Yeh \& Chang, 2020). Changes in development both in the region and in the country as a whole are mostly driven by economic development and the increase in economic productivity (Babu \& Datta, 2015; Bolcarova \& Kološta, 2015; Gedvilaite, 2019; Ginevičius et al., 2015; Ginevičius et al., 2018; Soava et al., 2020), so it is important for science and practice to be able to quantify it in order to understand and manage the development process in a more conscious and effective way. The economic development of the region is a multi-faceted and complex process that manifests itself in many different ways in reality. The state of such phenomena can only be quantified by indicators or indices that combine all these aspects.

There are two approaches in the literature to quantifying the status of such processes. It is a development assessment based on gross domestic product per capita in a region or country (GDP) (Babu \& Datta, 2015; Bolcarova \& Kološta, 2015; Chansara, 2013; Compagnolo et al., 2018; Čiegis et al., 2010; Golusin \& Munitlak, 2009; Janker \& Mann, 2018; Kareivaite, 2012; Kondyli, 2010; Radonovic \& Lior, 2017; Rametsteiner et al., 2011; Schoenoker et al., 2015; Strezov et al., 2017; Touceda et al., 2018; Turcu, 2013; Zinatiradet et al., 2017), and an integrated assessment of development based on multi-criteria approaches (Boggia \& Cortina, 2010; Chansarn, 2013; Delai \& Takahashi, 2011; Graymore et al., 2010; Grzebyk \& Stec, 2015; He et al., 2016; Ivanovic et al., 2009; Radonovich \& Lior, 2017; Sala et al., 2015; Wallis et al., 
2011; Wang et al., 2018; Xavier et al., 2018; Zinatiradet et al., 2017). The size of GDP and its changes are considered to adequately reflect the processes of successful economic development (Čiegis et al., 2010).

It is possible that the second method is more accurate, which allows combining the desired number of indicators reflecting upon different aspects of regional development into one aggregate size. On the other hand, the reasons for the limited use of this promising method for quantifying economic development are given. The main ones are the following (Becker et al., 2017; Boggia et al., 2014; Booysen, 2002; Chowdhury \& Squire, 2006; Golusin et al., 2011; Rogge, 2018; Verbunt \& Rogge, 2018; Zhou et al., 2010):

- authors use different indicators;

- a different number of indicators included in the evaluation system;

- limited access to data to calculate the values of indicators, resulting in inadequate indicator systems to reflect the phenomenon under consideration;

- high computational costs, as it is necessary to find not only the mean but also the importance of each indicator, which is usually determined by experts.

On the other hand, almost all authors include GDP per capita in the system as critical, among other essential indicators. It should be noted here that the inclusion of this indicator is not entirely appropriate, as it differs in its complexity from other indicators which reflect rather local aspects of development. An important factor in favour of GDP per capita as an indicator of economic development in countries or regions is that information on it is easily accessible and published regularly, especially at a country level. At the regional level, such data are available in national statistical publications. For example, in Poland it is published in Statistics Poland (Statistics Poland, n.d.), whereas in Lithuania it is published in Statistics Lithuania (Statistics Lithuania, n.d.) and so on.

For these reasons, the study of the dynamics of economic development in the regions of the countries concerned will be based on GDP per capita. The research is based on the principles of MDD methodology (Ginevičius et al., 2018). Its objective is to develop an aggregate indicator of development dynamics and to quantify the dynamics of the economic development of the Polish and Lithuanian regions. The employed methodological approach is based on the authors' definition of the mean of regional economic development equilibrium. The research questions are of the theoretical and empirical nature: Can an aggregate indicator of development dynamics provide valuable information on the region's condition? How do Polish and Lithuanian regions compare in terms of the economic development dynamics in the years 2007-2017?

The structure of the paper is as follows. First, the possibilities of quantifying the dynamics of the economic development in regions and countries is considered. Indicators of development intensity and development sustainability (continuity) are suggested as two principal components of development dynamics metrics. In the next section the relevant statistics of Polish and Lithuanian regions are studied. Development dynamics index for economic development of Polish and Lithuanian regions is calculated and the results are discussed. The paper ends with conclusions, description of limitations and the indication of the possible future research avenues. 


\section{Possibilities for quantifying the dynamics of economic development in the regions of the country}

First of all, it is worthwhile presenting the concept of development dynamics. It could be described as the change, evolution, or course of the phenomenon or process under consideration. Thus, the evaluation of dynamics is always related to a certain time span.

An analysis of the literature based on these provisions shows that our primary aim is to quantify the state of development of a country or region at a given point in time, which stands not for the dynamics of the process, but for the static state of its development.

Today, hundreds of indicator systems are used to assess the state of components of development (economic, social, environmental) (Čiegis et al., 2010; Hamilton, 2007; McLaren et al., 1998; Parris \& Kates, 2003; Ress, 2000; Rotmans, 2006; Scherp, 1994; Spangenberg, 2002; Wackernagel \& Ress, 1996).

In order to quantify the state of development of the phenomenon as a whole, hierarchical indicator systems of 3 to 4 levels are formed (Spanglenberg et al., 2002; Volkov, 2018). In essence, all these studies are designed to assess the state of development at a given point in time, i. e. not in their dynamics. In this way the development trends such as intensity, nature, etc. are not taken into account. Meanwhile, the inherent characteristic of any socio-economic system, as a prerequisite for its existence, is constant development, and in order to gain a deeper understanding of the process, it must be analysed and evaluated in their dynamics.

Tables 1 and 2 show the means of GDP per capita of the regions in the countries concerned, namely, Poland and Lithuania.

Table 1. GDP per capita in voivodeships in thousands PLN (source: Statistics Poland, n.d.)

\begin{tabular}{|l|c|c|c|c|c|c|c|c|c|c|c|}
\hline \multirow{2}{*}{\multicolumn{1}{c|}{ Voivodeship }} & \multicolumn{9}{|c|}{ Years } \\
\cline { 2 - 13 } & 2007 & 2008 & 2009 & 2010 & 2011 & 2012 & 2013 & 2014 & 2015 & 2016 & 2017 \\
\hline Dolnośląskie & 33.9 & 36.5 & 38.8 & 42.3 & 46.3 & 48.0 & 48.2 & 50.1 & 52.2 & 53.7 & 57.2 \\
\hline Kujawsko-Pomorskie & 26.9 & 29.0 & 29.7 & 31.1 & 33.2 & 34.4 & 35.3 & 36.4 & 38.2 & 39.5 & 41.9 \\
\hline Lubelskie & 21.7 & 24.0 & 24.5 & 25.9 & 28.3 & 29.6 & 30.4 & 31.2 & 32.1 & 33.4 & 35.6 \\
\hline Lubuskie & 27.8 & 29.3 & 30.4 & 31.7 & 33.7 & 35.1 & 35.8 & 37.6 & 39.1 & 40.6 & 42.8 \\
\hline Łódzkie & 28.9 & 31.3 & 32.8 & 34.7 & 37.6 & 39.4 & 40.1 & 41.7 & 43.8 & 45.2 & 48.4 \\
\hline Małopolskie & 27.7 & 30.3 & 31.7 & 32.9 & 36.1 & 37.3 & 38.2 & 39.8 & 42.2 & 43.9 & 47.3 \\
\hline Mazowieckie & 48.3 & 51.6 & 55.7 & 59.7 & 64.5 & 67.4 & 69.0 & 71.7 & 74.7 & 77.4 & 83.0 \\
\hline Opolskie & 26.2 & 29.0 & 29.9 & 30.8 & 33.2 & 34.2 & 34.6 & 36.3 & 37.8 & 38.6 & 41.2 \\
\hline Podkarpackie & 22.0 & 24.2 & 25.2 & 26.1 & 28.5 & 29.6 & 30.6 & 31.6 & 33.2 & 34.1 & 36.1 \\
\hline Podlaskie & 23.1 & 24.6 & 26.1 & 27.4 & 29.7 & 30.3 & 31.4 & 32.4 & 33.3 & 34.3 & 37.1 \\
\hline Pomorskie & 30.7 & 32.3 & 34.8 & 36.0 & 39.1 & 41.3 & 41.5 & 42.6 & 45.0 & 46.9 & 50.0 \\
\hline Śląskie & 32.9 & 36.1 & 38.3 & 40.2 & 43.7 & 44.9 & 44.8 & 46.5 & 48.7 & 50.2 & 53.5 \\
\hline Świętokrzyskie & 24.8 & 27.8 & 28.1 & 29.0 & 31.0 & 31.6 & 31.4 & 32.6 & 33.8 & 34.6 & 36.9 \\
\hline $\begin{array}{l}\text { Warmińsko- } \\
\text { Mazurskie }\end{array}$ & 23.0 & 24.9 & 26.0 & 27.2 & 29.3 & 30.2 & 30.8 & 32.0 & 33.2 & 34.5 & 36.4 \\
\hline Wielkopolskie区 & 32.9 & 35.7 & 38.4 & 39.5 & 42.8 & 44.8 & 46.2 & 48.0 & 50.8 & 52.8 & 56.5 \\
\hline Zachodniopomorskie & 27.5 & 30.2 & 30.8 & 32.1 & 34.1 & 35.5 & 35.9 & 37.5 & 39.6 & 40.6 & 43.1 \\
\hline
\end{tabular}


Table 2. GDP per capita at current prices in Lithuanian counties in thousands EUR (source: Statistics Lithuania, n.d.)

\begin{tabular}{|l|c|c|c|c|c|c|c|c|c|c|c|}
\hline \multirow{3}{*}{ County } & \multicolumn{10}{|c|}{ Year } \\
\cline { 2 - 14 } & 2007 & 2008 & 2009 & 2010 & 2011 & 2012 & 2013 & 2014 & 2015 & 2016 & 2017 \\
\hline Alytus & 5.8 & 6.8 & 5.6 & 6.0 & 6.9 & 7.2 & 7.6 & 8.1 & 8.2 & 8.5 & 9.4 \\
\hline Kaunas & 8.6 & 9.9 & 8.1 & 8.7 & 10.1 & 11.0 & 11.6 & 12.3 & 12.8 & 13.7 & 15.2 \\
\hline Klaipėda & 9.3 & 10.6 & 9.5 & 10.0 & 11.3 & 12.1 & 12.6 & 13.1 & 13.3 & 13.8 & 15.1 \\
\hline Marijampole & 5.4 & 6.4 & 5.1 & 5.8 & 6.5 & 7.3 & 7.6 & 7.9 & 7.9 & 8.1 & 9.1 \\
\hline Panevėžys & 6.3 & 7.5 & 6.2 & 6.6 & 7.7 & 8.4 & 8.8 & 9.3 & 9.7 & 10.0 & 11.0 \\
\hline Šiauliai & 6.5 & 7.4 & 6.0 & 6.7 & 7.8 & 8.5 & 8.9 & 9.3 & 9.6 & 10.3 & 11.5 \\
\hline Tauragė & 4.1 & 5.2 & 4.5 & 5.0 & 6.0 & 6.4 & 6.6 & 7.0 & 7.2 & 7.4 & 8.2 \\
\hline Telšiai & 7.5 & 8.7 & 6.9 & 7.6 & 8.8 & 9.0 & 9.2 & 9.1 & 9.4 & 9.6 & 10.7 \\
\hline Utena & 7.0 & 8.3 & 7.2 & 6.3 & 7.2 & 7.5 & 7.8 & 8.2 & 8.2 & 8.4 & 9.1 \\
\hline Vilnius & 13.8 & 15.2 & 12.6 & 13.2 & 14.7 & 15.9 & 17.1 & 18.1 & 18.7 & 19.6 & 21.3 \\
\hline
\end{tabular}

Tables 1 and 2 show that the dynamics of economic development are reflected upon three parameters: development intensity, continuity and duration of the period under consideration. The first two do change over time and are different for each region. The third parameter is the constant. In this case, the structure of the indicator of economic development dynamics of the country's region will look like this (Figure 1).

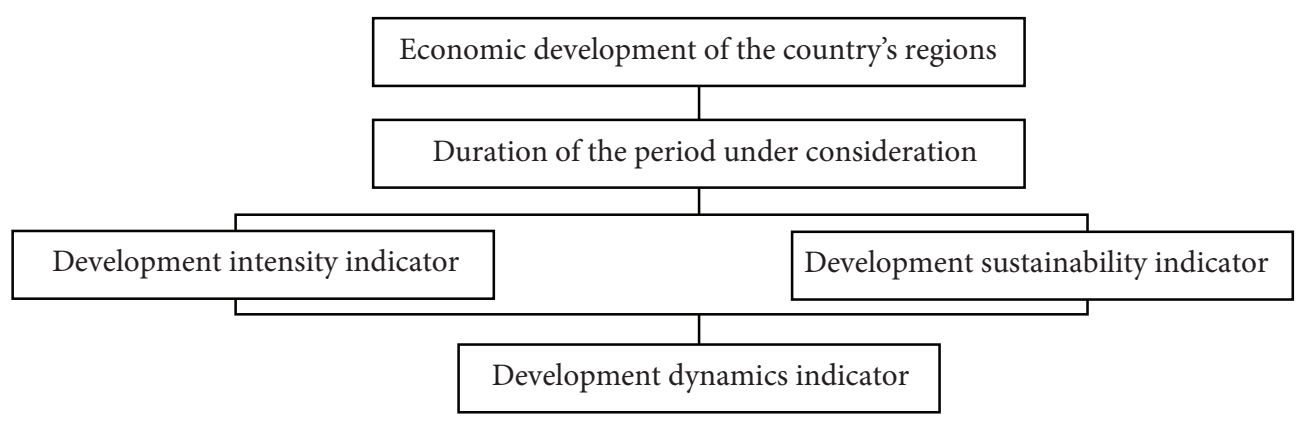

Figure 1. Structure of indicators of dynamics of economic development in the regions of the country (source: based on Ginevičius et al., 2018)

The indicator of regional development intensity of a country can be determined by the ratio of the GDP per capita of the region at the end of the period under review to the same value at the beginning of the period under consideration (Ginevičius et al., 2018):

$$
D_{k j}^{T I}=\frac{Q_{k j}^{T F}}{Q_{k j}^{T B}},
$$

where $D_{k j}^{T I}$ is the indicator of economic development intensity of region $j$ of country $k$ during the period under consideration $T$; $Q_{k j}^{T F}$ - the value of GDP per capita of region $j$ of country $k$ at the end of period $T$; and is the $Q_{k j}^{T B}$ same at the beginning of the period. 
The mean $D_{k j}^{T I}$ is dimensionless and relative, so it can be used to compare different entities, e.g., when one is expressed, for example, in PLN and the other is in EUR (Lithuania).

The indicator of economic development dynamics combines the intensity and uniformity of development (Figure 1), therefore it is necessary to determine their relation. An analysis of the data in Table 1 and Table 2 show that whereas the intensity of development increases, the uniformity of development decreases. This means that in order to adequately assess the dynamics of development, it is necessary to eliminate the influence of indicator of the development intensity on the sustainability of development. This can be done by relying solely on differences in economic development over particular periods of time such as years. They may be represented either by the relationship between the development values of two adjacent time periods or by the difference between these values. Calculations completed have showed that the development situation is more accurately reflected by differences in development values of adjacent time periods (Ginevičius et al., 2018). We will set them this way (Figure 2).

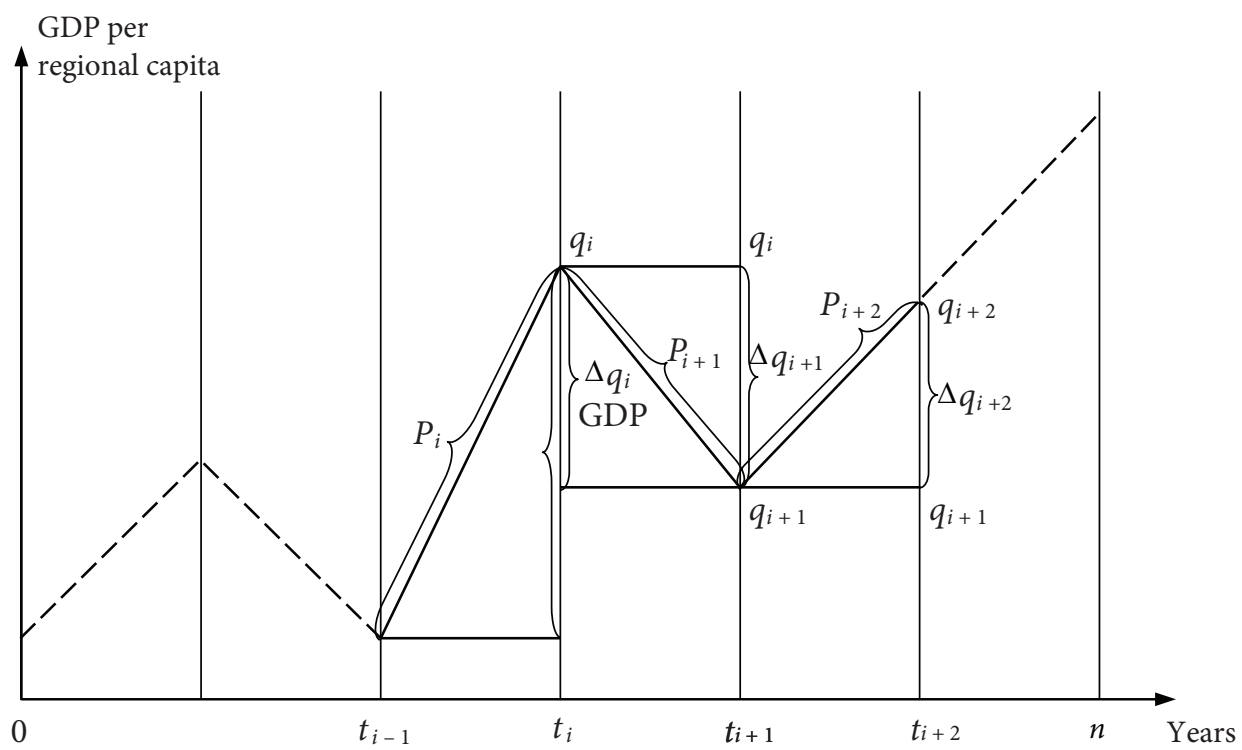

Figure 2. Differences in the economic development of a region of a country over time periods (differences in the economic development values over the period $\Delta q i-i-0$ ) (source: completed by authors based on Ginevičius et al., 2018)

Differences $\Delta q_{i}$ in economic development of the region shown on Figure 2. At the individual periods of time $\left(t_{i}-t_{i+1}\right)$ will be determined as follows:

$$
\begin{gathered}
\Delta q_{i}=q_{i+1}-q_{i} ; \\
\Delta q_{i+1}=q_{i+1}-q_{i+2} \text { etc. }
\end{gathered}
$$

where $q_{i}$ - is the value of the economic development indicator at the beginning of period $t_{i}$.

The essence of the methodology used in this study is that the mean of regional economic development equilibrium is defined as the ratio of the value that reflects the duration of the period under consideration to the actual duration of the development trajectory (Ginevičius et al., 2018): 


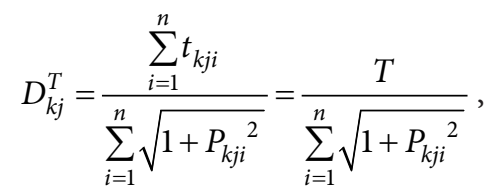

where $D_{j}^{T}$ is the indicator for the economic development of the region of country $j ; P_{i}$ is the diagonal length $q_{i} q_{i+1} q_{i}$ of the right triangle $i$ (Figure 2 ); $t_{i}$ - duration of period $i\left(t_{i}=1\right.$ ); and $n$ is the number of time periods of the time span under consideration.

Based on this methodology, the indicators of economic development intensity, continuity and dynamics of Polish and Lithuanian regions were determined.

\section{Calculation of dynamics index for economic development of Polish and Lithuanian regions}

Based on the above methodology, first of all, it is necessary to calculate the indicator of the intensity of economic development of the regions of the country during the period under consideration (Figure 1, formula (1)). The calculation results are shown in Table 3.

Table 3. Economic development intensity of Polish and Lithuanian regions over the period of 2008-2017 (source: compiled by authors based on Ginevičius et al., 2018)

\begin{tabular}{|l|c|l|c|}
\hline \multicolumn{2}{|c|}{ Poland } & \multicolumn{2}{c|}{ Lithuania } \\
\hline $\begin{array}{c}\text { Name of the region } \\
\text { (voivodeship) }\end{array}$ & $\begin{array}{c}\text { Mean of intensity } \\
\text { indicator }\end{array}$ & $\begin{array}{c}\text { Name of region } \\
\text { (county) }\end{array}$ & $\begin{array}{c}\text { Mean of intensity } \\
\text { indicator }\end{array}$ \\
\hline Dolnośląskie & 1.57 & Alytus & 1.38 \\
\hline Kujawsko-Pomorskie & 1.44 & Kaunas & 1.54 \\
\hline Lubelskie & 1.48 & Klaipèda & 1.42 \\
\hline Lubuskie & 1.46 & Marijampolè & 1.42 \\
\hline Łódzkie & 1.55 & Panevěžys & 1.47 \\
\hline Małopolskie & 1.56 & Šiauliai & 1.55 \\
\hline Mazowieckie & 1.61 & Tauragé & 1.58 \\
\hline Opolskie & 1.42 & Telšiai & 1.23 \\
\hline Podkarpackie & 1.49 & Utena & 1.10 \\
\hline Podlaskie & 1.51 & Vilnius & \\
\hline Pomorskie & 1.55 & & \\
\hline Śląskie & 1.48 & & \\
\hline Świętokrzyskie & 1.28 & & \\
\hline Warmińsko-Mazurskie & 1.46 & & \\
\hline Wielkopolskie & 1.58 & & \\
\hline Zachodniopomorskie & 1.43 & & \\
\hline
\end{tabular}

From formula (4) it can be seen that the uniformity indicator of economic development ranges from 0 to 1 . In order to calculate the indicator of dynamics of development, along with intensity and uniformity, it is necessary to combine them into one aggregated measure 
(Figure 1). Consequently, the intensity indicator should also vary within the same range, ie. y. 0 to 1 . For this purpose, the data in Table 3 shall be transformed as follows:

$$
\tilde{D}_{k j}^{T I}=\frac{D_{k j}^{T I}}{D_{k \max }^{T I}},
$$

where $\tilde{D}_{k j}^{T I}$ is a transformed mean of economic development intensity of region $j$ of country $k$; where $D_{k \max }^{T I}$ is a mean of the economic development intensity of the country $k$ for the region for which it is highest.

A comprehensive analysis of countries' economic development also requires comparisons between them. This can be done as follows:

$$
\tilde{\tilde{D}}_{k j}^{T I}=\frac{Q_{k j}^{T I}}{\tilde{Q}_{\max }^{T I}},
$$

where $\tilde{D}_{k j}^{T I}$ is the $T$-value of the economic development intensity of region $j$ of the country $k$ that takes into account the economic development context of the other country; $\tilde{Q}_{\max }^{T I}$ is the value of the intensity of economic development over the reference period $T$ for the region of the countries in question where it is highest.

The size and calculation results of values $\tilde{D}^{T I}$ and $\tilde{\tilde{D}}^{T I}$ are shown in Table 4.

Table 4. The results of intensity calculation of economic development in Polish and Lithuanian regions

\begin{tabular}{|c|c|c|c|c|c|}
\hline \multicolumn{3}{|c|}{ Poland } & \multicolumn{3}{|c|}{ Lithuania } \\
\hline \multirow{2}{*}{$\begin{array}{l}\text { Name of the region } \\
\quad \text { (voivodeship) }\end{array}$} & \multicolumn{2}{|c|}{$\begin{array}{l}\text { Mean of intensity } \\
\text { indicator }\end{array}$} & \multirow{2}{*}{$\begin{array}{l}\text { Name of region } \\
\text { (county) }\end{array}$} & \multicolumn{2}{|c|}{$\begin{array}{l}\text { Mean of intensity } \\
\text { indicator }\end{array}$} \\
\hline & $\tilde{D}^{T I}$ & $\tilde{\tilde{D}}^{T I}$ & & $\tilde{D}^{T I}$ & $\tilde{\tilde{D}}^{T I}$ \\
\hline Dolnośląskie & 0.98 & 0.98 & Alytaus & 0.87 & 0.86 \\
\hline Kujawsko-Pomorskie & 0.89 & 0.89 & Kauno & 0.97 & 0.96 \\
\hline Lubelskie & 0.92 & 0.92 & Klaipèdos & 0.90 & 0.88 \\
\hline Lubuskie & 0.91 & 0.91 & Marijampolès & 0.90 & 0.88 \\
\hline Łódzkie & 0.96 & 0.96 & Panevėžio & 0.93 & 0.91 \\
\hline Małopolskie & 0.97 & 0.97 & Šiaulių & 0.98 & 0.96 \\
\hline Mazowieckie & 1.00 & 1.00 & Tauragès & 1.00 & 0.98 \\
\hline Opolskie & 0.88 & 0.88 & Telšių & 0.78 & 0.76 \\
\hline Podkarpackie & 0.93 & 0.93 & Utenos & 0.70 & 0.68 \\
\hline Podlaskie & 0.94 & 0.94 & Vilniaus & 0.87 & 0.87 \\
\hline Pomorskie & 0.96 & 0.96 & Average & 0.89 & 0.87 \\
\hline Śląskie & 0.92 & 0.92 & & & \\
\hline Świętokrzyskie & 0.83 & 0.83 & & & \\
\hline Warmińsko-Mazurskie & 0.91 & 0.91 & & & \\
\hline Wielkopolskie & 0.98 & 0.98 & & & \\
\hline Zachodniopomorskie & 0.89 & 0.89 & & & \\
\hline Average & 0.93 & 0.93 & & & \\
\hline
\end{tabular}
2008-2017 (source: compiled by authors) 
Table 4 shows that the economic development of regions of Poland during 2008-2017, was more intensive than of regions of Lithuania.

The results of the calculation of the indicator for the economic development of the Polish and Lithuanian regions according to formula (4) are presented in Table 5.

Table 5. The calculation results for economic development in Poland and Lithuania over 2008-2017 (source: compiled by the authors)

\begin{tabular}{|l|c|l|c|}
\hline \multicolumn{2}{|c|}{ Poland } & \multicolumn{2}{c|}{ Lithuania } \\
\hline $\begin{array}{c}\text { Name of the region } \\
\text { (voivodeship) }\end{array}$ & $\begin{array}{c}\text { Mean of } D^{T} \\
\text { indicator }\end{array}$ & \multicolumn{1}{c|}{$\begin{array}{c}\text { Name of region } \\
\text { (county) }\end{array}$} & $\begin{array}{c}\text { Mean of } D^{T} \\
\text { indicator }\end{array}$ \\
\hline Dolnośląskie & 0.56 & Alytaus & 0.80 \\
\hline Kujawsko-Pomorskie & 0.64 & Kauno & 0.71 \\
\hline Lubelskie & 0.65 & Klaipèdos & 0.75 \\
\hline Lubuskie & 0.63 & Marijampolès & 0.86 \\
\hline tódzkie & 0.59 & Panevéžio & 0.77 \\
\hline Małopolskie & 0.59 & Šiaulių & 0.75 \\
\hline Mazowieckie & 0.48 & Tauragès & 0.81 \\
\hline Opolskie & 0.64 & Telšių & 0.78 \\
\hline Podkarpackie & 0.65 & Utenos & 0.86 \\
\hline Podlaskie & 0.65 & Vilniaus & 0.67 \\
\hline Pomorskie & 0.62 & Average & 0.78 \\
\hline Śląskie & 0.58 & & \\
\hline Świętokrzyskie & 0.67 & & \\
\hline Warmińsko-Mazurskie & 0.66 & & \\
\hline Wielkopolskie & 0.55 & & \\
\hline Zachodniopomorskie & 0.63 & & \\
\hline Average & 0.61 & & \\
\hline
\end{tabular}

Table 5 shows that the regions of Lithuania developed in a more economically even way in the period of 2008-2017 than the regions of Poland. This is logical, as the development of Lithuanian regions during this period was developping less intensively.

The integrated indicator of the economic development dynamics of the regions of the countries will be obtained by combining the indicators of intensity and uniformity into one aggregated measure (Figure 1). This can be done as follows (Ginevičius et al., 2018):

$$
\begin{aligned}
& D_{k j}^{T D}=\tilde{D}_{k j}^{T I} \times D_{k j}^{T} ; \\
& \tilde{D}_{k j}^{T D}=\tilde{\tilde{D}}_{k j}^{T I} \times D_{k j}^{T},
\end{aligned}
$$

$D_{k j}^{T D}$ here is an indicator of the economic development dynamics of region $j$ of country $k$.

The results of the calculations for indicators $D_{k j}^{D}$ and $\tilde{D}_{k j}^{D}$ for the Polish and Lithuanian regions are presented in Table 6. 
Table 6. Values of economic development dynamics of Polish and Lithuanian regions in 2008-2017 (source: compiled by authors)

\begin{tabular}{|c|c|c|c|c|c|}
\hline \multicolumn{3}{|c|}{ Poland } & \multicolumn{3}{|c|}{ Lithuania } \\
\hline \multirow{2}{*}{$\begin{array}{l}\text { Name of the region } \\
\text { (voivodeship) }\end{array}$} & \multicolumn{2}{|c|}{$\begin{array}{l}\text { The value of the } \\
\text { dynamic index }\end{array}$} & \multirow{2}{*}{$\begin{array}{l}\text { Name of region } \\
\text { (county) }\end{array}$} & \multicolumn{2}{|c|}{$\begin{array}{l}\text { The value of the } \\
\text { dynamic index }\end{array}$} \\
\hline & $D^{T D}$ & $\tilde{D}^{T D}$ & & $D^{T D}$ & $\tilde{D}^{T D}$ \\
\hline Dolnośląskie & 0.55 & 0.55 & Alytus & 0.70 & 0.69 \\
\hline Kujawsko-Pomorskie & 0.57 & 0.57 & Kaunas & 0.69 & 0.68 \\
\hline Lubelskie & 0.60 & 0.60 & Klaipèda & 0.68 & 0.66 \\
\hline Lubuskie & 0.57 & 0.57 & Marijampolè & 0.77 & 0.76 \\
\hline Łódzkie & 0.57 & 0.57 & Panevėžys & 0.72 & 0.70 \\
\hline Małopolskie & 0.57 & 0.57 & Šiauliai & 0.74 & 0.72 \\
\hline Mazowieckie & 0.48 & 0.48 & Tauragè & 0.81 & 0.79 \\
\hline Opolskie & 0.56 & 0.56 & Telšiai & 0.61 & 0.59 \\
\hline Podkarpackie & 0.60 & 0.60 & Utena & 0.60 & 0.58 \\
\hline Podlaskie & 0.61 & 0.61 & Vilnius & 0.75 & 0.58 \\
\hline Pomorskie & 0.60 & 0.60 & Average & 0.71 & 0.68 \\
\hline Śląskie & 0.53 & 0.53 & & & \\
\hline Świętokrzyskie & 0.57 & 0.57 & & & \\
\hline Warmińsko-Mazurskie & 0.60 & 0.60 & & & \\
\hline Wielkopolskie & 0.54 & 0.54 & & & \\
\hline Zachodniopomorskie & 0.56 & 0.56 & & & \\
\hline Average & 0.57 & 0.57 & & & \\
\hline
\end{tabular}

Formula (5) assumes that both the intensity and continuity of economic development in a region are equivalent in importance to the dynamics of development. The situation may change if this importance is re-assessed. Logic says that short-term fluctuations in economic development over particular periods of the time span under consideration have a significantly lesser impact on the social and ecological status of the country's regions than on the intensity of development, which is indicative of long-term economic prosperity.

This hypothesis was verified by expert peer review. The importance of the intensity of economic development of the country's region for its dynamics was estimated by experts at per cent out of 100 and correspondingly the importance of continuity at 25 per cent. In this case, formula (5) can be transformed as follows (Hwang \& Yoon, 1981):

$$
\tilde{D}_{k j}^{T D}=\omega^{I} D_{k i}^{T J}+\omega^{T} D_{k i}^{T}
$$

where $\tilde{D}_{k j}^{T D}$ is the dynamics indicator of economic development of region $j$ of country $k$ during the period under consideration $T$, which assesses the importance of development intensity and development continuity for development dynamics; and $\omega^{I}$ is the indicator of the importance of development intensity to its dynamics; whereas $\omega^{T}$ is an indicator of the importance of development continuity to its dynamics. 
The values $\omega^{I}$ and $\omega^{T}$ are expressed in partitives of units, so the condition: $\omega^{I}+\omega^{T}=1$ applies.

The results of calculations assessing the importance of development intensity and continuity for the indicators of development dynamics during the period 2008-2017 for the economic development of regions in Poland and Lithuania 2008-2017 are presented in Table 7.

Table 7. The values of the indicator economic development dynamics of Polish and Lithuanian regions 2008-2017 assessing the significance of development intensity and continuity for the indicator of development dynamics (source: compiled by the authors)

\begin{tabular}{|c|c|c|c|c|c|}
\hline \multicolumn{3}{|c|}{ Poland } & \multicolumn{3}{|c|}{ Lithuania } \\
\hline \multirow{2}{*}{$\begin{array}{l}\text { Name of the region } \\
\text { (voivodeship) }\end{array}$} & \multicolumn{2}{|c|}{$\begin{array}{l}\text { The value of the } \\
\text { dynamic index }\end{array}$} & \multirow{2}{*}{$\begin{array}{l}\text { Name of region } \\
\text { (county) }\end{array}$} & \multicolumn{2}{|c|}{$\begin{array}{l}\text { The value of the } \\
\text { dynamic index }\end{array}$} \\
\hline & $D_{D}$ & $\tilde{D}_{D}$ & & $D_{D}$ & $\tilde{D}_{D}$ \\
\hline Dolnośląskie & 0.88 & 0.88 & Alytus & 0.86 & 0.84 \\
\hline Kujawsko-Pomorskie & 0.83 & 0.83 & Kaunas & 0.91 & 0.90 \\
\hline Lubelskie & 0.85 & 0.85 & Klaipèda & 0.86 & 0.85 \\
\hline Lubuskie & 0.84 & 0.84 & Marijampolè & 0.89 & 0.88 \\
\hline Łódzkie & 0.87 & 0.87 & Panevėžys & 0.89 & 0.87 \\
\hline Małopolskie & 0.88 & 0.88 & Šiauliai & 0.92 & 0.91 \\
\hline Mazowieckie & 0.87 & 0.87 & Tauragė & 0.95 & 0.94 \\
\hline Opolskie & 0.82 & 0.82 & Telšiai & 0.78 & 0.76 \\
\hline Podkarpackie & 0.86 & 0.86 & Utena & 0.74 & 0.73 \\
\hline Podlaskie & 0.87 & 0.87 & Vilnius & 0.82 & 0.82 \\
\hline Pomorskie & 0.88 & 0.88 & Average & 0.86 & 0.85 \\
\hline Śląskie & 0.84 & 0.84 & & & \\
\hline Świętokrzyskie & 0.79 & 0.79 & & & \\
\hline Warmińsko-Mazurskie & 0.85 & 0.85 & & & \\
\hline Wielkopolskie & 0.87 & 0.87 & & & \\
\hline Zachodniopomorskie & 0.83 & 0.83 & & & \\
\hline Average & 0.85 & 0.85 & & & \\
\hline
\end{tabular}

In order to summarize the results of the analysis of the economic development of the Polish and Lithuanian regions, it is necessary to determine the statistical characteristics of the calculated indicators - e.g. intensity, uniformity and dynamics - as random variables. The basic ones are: arithmetic average mean, average square deviation, dispersion, moda, median, coefficients of asymmetries and of variation. The brief description is provided in Table 8 .

More accurate statistical characteristic values in Table 8 are obtained when the data are not grouped, namely, when they are not represented by interval distribution lines. On the other hand, interval expression of the data makes the calculations simpler. Therefore, part of the statistical characteristics $(\bar{x}, \sigma, \sigma 2, K a, V)$ is calculated on the basis of ungrouped data, while the moda and median are grouped. The interval distribution of the lines is presented in Table 9. 
Table 8. Statistical characteristics of analysis of economic development indicators of Polish and Lithuanian regions (source: compiled by authors)

\begin{tabular}{|c|l|l|}
\hline No. & \multicolumn{1}{|c|}{$\begin{array}{c}\text { Name of the statistical } \\
\text { characteristic }\end{array}$} & \multicolumn{1}{|c|}{ Description of statistical characteristic } \\
\hline 1 & Simple arithmetic mean $(\bar{x})$ & $\begin{array}{l}\text { The average value of all available numeric values. This is } \\
\text { the typical level of a variable trait in specific location and } \\
\text { time conditions }\end{array}$ \\
\hline 2 & Mean square deviation $(\sigma)$ & $\begin{array}{l}\text { Displays the average distance of the attribute values from } \\
\text { the mean, i.e. it is a measure of scattering }\end{array}$ \\
\hline 3 & Dispersion $\left(\sigma^{2}\right)$ & Shows how values are dispersed across the whole \\
\hline 4 & Moda $(\mathrm{Mo})$ & $\begin{array}{l}\text { The most common recurring value of a variable in a given } \\
\text { population }\end{array}$ \\
\hline 5 & Mediana $(\mathrm{Me})$ & $\begin{array}{l}\text { The value of an attribute that divides a ranked distribution } \\
\text { line into two equal parts }\end{array}$ \\
\hline 6 & Asymmetry coefficient $(\mathrm{Ka})$ & $\begin{array}{l}\text { Describes the peculiarities of line distribution in horizontal } \\
\text { direction }\end{array}$ \\
\hline 7 & Coefficient of variation $(\mathrm{V})$ & $\begin{array}{l}\text { Shows the degree (in per cent) of the average value of } \\
\text { a variable at which it is distant from the given attribute } \\
\text { values, i.e. it is a numerical characteristic of the dispersion } \\
\text { of values }\end{array}$ \\
\hline
\end{tabular}

Table 9. Intervals of economic development indicators of Polish and Lithuanian regions (source: compiled by authors)

\begin{tabular}{|c|c|c|c|c|c|c|c|c|}
\hline \multirow{3}{*}{ Indicators } & \multicolumn{4}{|c|}{ Poland } & \multicolumn{4}{|c|}{ Lithuania } \\
\hline & \multicolumn{2}{|l|}{$D_{i}^{P J}$} & \multicolumn{2}{|l|}{$\tilde{D}_{i}^{P J}$} & \multicolumn{2}{|c|}{$D_{i}^{P J}$} & \multicolumn{2}{|c|}{$\tilde{D}_{i}^{P J}$} \\
\hline & intervals & $\begin{array}{l}\text { fre- } \\
\text { quen- } \\
\text { cies }\end{array}$ & intervals & $\begin{array}{l}\text { fre- } \\
\text { quen- } \\
\text { cies }\end{array}$ & intervals & $\begin{array}{l}\text { fre- } \\
\text { quen- } \\
\text { cies }\end{array}$ & intervals & $\begin{array}{l}\text { fre- } \\
\text { quen- } \\
\text { cies }\end{array}$ \\
\hline \multirow{5}{*}{$\begin{array}{l}\text { Intensity of } \\
\text { economic } \\
\text { development }\end{array}$} & $0.80-0.84$ & 1 & $0.80-0.84$ & 1 & $0.70-0.78$ & 2 & $0.65-0.72$ & 1 \\
\hline & $0.84-0.88$ & 1 & $0.84-0.88$ & 1 & $0.78-0.86$ & 0 & $0.72-0.79$ & 1 \\
\hline & $0.88-0.92$ & 6 & $0.88-0.92$ & 6 & $0.86-0.94$ & 5 & $0.79-0.86$ & 1 \\
\hline & $0.92-0.96$ & 4 & $0.92-0.96$ & 4 & $0.94-1.02$ & 3 & $0.86-0.93$ & 4 \\
\hline & $0.96-1.00$ & 4 & $0.96-1.00$ & 4 & - & - & $0.93-1.00$ & 3 \\
\hline \multirow{6}{*}{$\begin{array}{l}\text { Uniformity } \\
\text { of economic } \\
\text { development }\end{array}$} & \multicolumn{2}{|c|}{ intervals } & \multicolumn{2}{|c|}{ frequency } & \multicolumn{2}{|c|}{ intervals } & \multicolumn{2}{|c|}{ frequency } \\
\hline & \multicolumn{2}{|c|}{$0.45-0.50$} & \multicolumn{2}{|c|}{1} & \multicolumn{2}{|c|}{$0.64-0.69$} & \multicolumn{2}{|c|}{1} \\
\hline & \multicolumn{2}{|c|}{$0.50-0.55$} & \multicolumn{2}{|l|}{1} & \multicolumn{2}{|c|}{$0.69-0.74$} & \multicolumn{2}{|l|}{1} \\
\hline & \multicolumn{2}{|c|}{$0.55-0.60$} & \multicolumn{2}{|l|}{4} & \multicolumn{2}{|c|}{$0.74-0.79$} & \multicolumn{2}{|l|}{4} \\
\hline & \multicolumn{2}{|c|}{$0.60-0.65$} & \multicolumn{2}{|l|}{8} & \multicolumn{2}{|c|}{$0.79-0.84$} & \multicolumn{2}{|l|}{2} \\
\hline & \multicolumn{2}{|c|}{$0.65-0.70$} & \multicolumn{2}{|l|}{2} & \multicolumn{2}{|c|}{$0.84-0.89$} & \multicolumn{2}{|l|}{2} \\
\hline \multirow{5}{*}{$\begin{array}{l}\text { Economic deve- } \\
\text { lopment dy- } \\
\text { namics without } \\
\text { consideration of } \\
\text { the importance } \\
\text { of indicators }\end{array}$} & $0.46-0.50$ & 1 & $0.46-0.50$ & 1 & $0.59-0.64$ & 2 & $0.57-0.62$ & 3 \\
\hline & $0.50-0.54$ & 2 & $0.50-0.54$ & 2 & $0.64-0.69$ & 2 & $0.62-0.67$ & 1 \\
\hline & $0.54-0.58$ & 8 & $0.54-0.58$ & 8 & $0.69-0.74$ & 3 & $0.67-0.72$ & 4 \\
\hline & $0.58-0.62$ & 5 & $0.58-0.62$ & 5 & $0.74-0.79$ & 2 & $0.72-0.77$ & 1 \\
\hline & & & & & $0.79-0.84$ & 1 & $0.77-0.82$ & 1 \\
\hline
\end{tabular}


End of Table 9

\begin{tabular}{|l|c|c|c|c|c|c|c|c|}
\hline \multirow{4}{*}{ Indicators } & \multicolumn{4}{|c|}{ Poland } & \multicolumn{4}{c|}{ Lithuania } \\
\cline { 2 - 10 } & \multicolumn{2}{|c|}{$D_{i}^{P J}$} & \multicolumn{2}{|c|}{$\tilde{D}_{i}^{P J}$} & \multicolumn{2}{|c|}{$D_{i}^{P I}$} & \multicolumn{2}{c|}{$\tilde{D}_{i}^{P I}$} \\
\cline { 2 - 10 } & intervals & $\begin{array}{c}\text { fre- } \\
\text { quen- } \\
\text { cies }\end{array}$ & intervals & $\begin{array}{c}\text { fre- } \\
\text { quen- } \\
\text { cies }\end{array}$ & intervals & $\begin{array}{c}\text { fre- } \\
\text { quen- } \\
\text { cies }\end{array}$ & intervals & $\begin{array}{c}\text { fre- } \\
\text { quen- } \\
\text { cies }\end{array}$ \\
\hline $\begin{array}{l}\text { Dynamics } \\
\text { of economic } \\
\text { development } \\
\text { considering the } \\
\text { importance of } \\
\text { indicators }\end{array}$ & $0.78-0.80$ & 1 & $0.78-0.80$ & 1 & $0.72-0.77$ & 1 & $0.73-0.78$ & 2 \\
\cline { 2 - 10 } & $0.80-0.82$ & 1 & $0.80-0.82$ & 1 & $0.77-0.82$ & 2 & $0.78-0.83$ & 1 \\
\cline { 2 - 10 } & $0.82-0.84$ & 4 & $0.82-0.84$ & 4 & $0.82-0.87$ & 2 & $0.83-0.88$ & 4 \\
\cline { 2 - 10 } & $0.86-0.86$ & 3 & $0.84-0.86$ & 3 & $0.87-0.92$ & 4 & $0.88-0.93$ & 2 \\
\hline
\end{tabular}

Based on Tables 4 to 7, the values of the statistical characteristics listed in Table 8 for the economic development of the Polish and Lithuanian regions were calculated. The results of the calculations are shown in Table 10.

Table 10. Means of statistical characteristics of economic development indicators of Polish and Lithuanian regions in 2008-2017 (source: compiled by authors)

\begin{tabular}{|c|c|c|c|c|c|c|c|c|}
\hline \multirow{2}{*}{\multicolumn{2}{|c|}{ Indicators }} & \multicolumn{7}{|c|}{ Poland } \\
\hline & & $\bar{x}$ & $\sigma$ & $\sigma^{2}$ & Mo & $\mathrm{Me}$ & $\mathrm{Ka}$ & $\mathrm{V}$ \\
\hline \multirow{2}{*}{ Intensity } & $D^{T J}$ & 0.93 & 0.043 & 0.0018 & 0.91 & 0.92 & 0.69 & 4.62 \\
\hline & $\tilde{D}^{T J}$ & 0.93 & 0.043 & 0.0018 & 0.91 & 0.92 & 0.69 & 4.62 \\
\hline Uniformity & $D^{T I}$ & 0.61 & 0.049 & 0.0024 & 0.62 & 0.61 & 0 & 8.03 \\
\hline \multirow{2}{*}{ Dynamics } & $D^{T D}$ & 0.57 & 0.033 & 0.0011 & 0.57 & 0.61 & -3.6 & 5.79 \\
\hline & $\tilde{D}^{T D}$ & 0.57 & 0.033 & 0.0018 & 0.57 & 0.61 & -3.6 & 5.79 \\
\hline \multirow{2}{*}{ Dynamics } & & 0.85 & 0.025 & 0.0006 & 0.87 & 0.85 & 0 & 2.94 \\
\hline & & 0.85 & 0.025 & 0.0006 & 0.87 & 0.85 & 0 & 2.94 \\
\hline \multirow{2}{*}{\multicolumn{2}{|c|}{ Indicators }} & \multicolumn{7}{|c|}{ Lithuania } \\
\hline & & $\bar{x}$ & $\sigma$ & $\sigma^{2}$ & Mo & $\mathrm{Me}$ & $\mathrm{Ka}$ & $\mathrm{V}$ \\
\hline \multirow{2}{*}{ Intensity } & $D^{T J}$ & 0.89 & 0.088 & 0.008 & 0.092 & 0.91 & 0.68 & 9.89 \\
\hline & $\tilde{D}^{T J}$ & 0.87 & 0.079 & 0.008 & 0.091 & 0.90 & 1.01 & 10.23 \\
\hline Uniformity & $D^{T I}$ & 0.78 & 0.056 & 0.0032 & 0.77 & 0.78 & 0 & 7.18 \\
\hline \multirow{2}{*}{ Dynamics } & $D^{T D}$ & 0.71 & 0.063 & 0.0040 & 0.72 & 0.71 & 0 & 8.87 \\
\hline & $\tilde{D}^{T D}$ & 0.68 & 0.070 & 0.0049 & 0.70 & 0.68 & 0 & 10.29 \\
\hline \multirow{2}{*}{ Dynamics } & & 0.86 & 0.062 & 0.0038 & 0.89 & 0.857 & +0.48 & 7.21 \\
\hline & & 0.85 & 0.062 & 0.0039 & 0.86 & 0.86 & -0.48 & 7.29 \\
\hline
\end{tabular}

Based on the results of Table 10, some generalizations of the development of Polish and Lithuanian regions can be made. These are shown in Table 11. 
Table 11. Summary of statistical characteristics of Economic Development in Polish and Lithuanian regions 2008-2017 (source: compiled by authors)

\begin{tabular}{|l|l|}
\hline $\begin{array}{c}\text { Statistical Characteristics } \\
\text { of Economic } \\
\text { Development in the } \\
\text { Region }\end{array}$ & Conclusions \\
\hline Arithmetic mean & $\begin{array}{l}\text { The mean of the coefficient of variation is insignificant, so it can be } \\
\text { stated that the calculated arithmetic mean is a sufficiently accurate } \\
\text { characteristic of the economic development of both Polish and } \\
\text { Lithuanian regions. On the other hand, this statement is much more } \\
\text { appropriate for Polish regions }\end{array}$ \\
\hline $\begin{array}{l}\text { Mean square deviation } \\
\text { and variance }\end{array}$ & $\begin{array}{l}\text { As the coefficient of variation, which binds the average square deviation } \\
\text { to the arithmetic mean is of insignificant importance, the dispersion of } \\
\text { the arithmetic mean of all indicators of economic development is small }\end{array}$ \\
\hline Moda & $\begin{array}{l}\text { The most common values for the intensity of economic development } \\
\text { in both Poland and Lithuania are in the relatively narrow range of } 0.91 \\
\text { to 0.92. The same cannot be said for the uniformity and partly for the } \\
\text { dynamics of the next characteristics }\end{array}$ \\
\hline Mediana & $\begin{array}{l}\text { Both Poland and Lithuania have more regions with economic } \\
\text { development intensities above 0.92; and 50 per cent of all regions do not } \\
\text { exceed this limit }\end{array}$ \\
\hline Asymmetry coefficient & $\begin{array}{l}\text { Both regions of Poland and Lithuania have a symmetric distribution of } \\
\text { economic development indicators. A slight right-sided asymmetry is } \\
\text { observed }\end{array}$ \\
\hline Coefficient of variation & $\begin{array}{l}\text { Both Poland and Lithuania have low variations in economic } \\
\text { development, as they do not exceed 30 per cent. On the other hand, it } \\
\text { is twice as big for Lithuanian regions as for Polish regions. From this } \\
\text { it can be concluded that the regions of Poland are developing more } \\
\text { economically stably compared to the regions of Lithuania }\end{array}$ \\
\hline
\end{tabular}

In conclusion, there are no significant differences in the dynamics of economic development between the regions of Poland and Lithuania. On the other hand, the regions of Poland are developping economically more intensely compared to the regions of Lithuania, while the regions of Lithuania are characterized by a more uniform economic development.

\section{Conclusions}

Countries are paying increasing attention to regional policy and to various factors influencing regional development with special focus on technology and innovation. This is because regional development inequalities exacerbate social tensions, which are manifested by negative processes such as external and internal emigration, crime, rising unemployment, falling birth rates, and so on. The region's overall competitiveness is declining. In order to reduce regional disparities in development, consecutive and effective strategies are needed to be launched. One of the essential conditions for their formation and successful implementation is the ability to quantify the current situation at a desired point in time.

The overall development of the country's region is based on economic development. Today, there are two fundamental approaches to this kind of quantification. It is an assessment 
based on gross domestic product per capita, and an integrated assessment using multi-criteria approaches. Notwithstanding the potential of the latter approach, the study relies on gross domestic product as it is unanimously recognized as one of the most important indicators reflecting upon the country's economic development. In addition, information about it is easily available. Its content is similar and can therefore be used to compare countries or their regions.

It is expedient to quantify the economic development of the regions of the country on the basis of the intensity, continuity and dynamics of economic development, which combine the former two. The values of these indicators can be determined based on the MDD methodology present in scientific publications.

Based on this methodology, the impact of the intensity of the economic development of the regions of the country on its uniformity, as well as the economic development situation of the regions of Poland and Lithuania were determined. The countries were compared to each other. The main limitation of the study is related to its low predictive potential and thus limited usefulness for policy makers in formulating plans and policy instruments for the future. To overcome this shortcoming, the methodology applied in this paper could be further developed to take into account discontinuities (unprecedented events) and to include elements of scenario methodology.

The overall conclusion is that there are no significant differences in the economic development dynamics of the regions of these countries. On the other hand, the regions of Poland are more economically developed as compared to the regions of Lithuania, while the regions of Lithuania are characterized by a more uniform economic development.

\section{Disclosure statement}

Authors declare no conflict of interest.

\section{References}

Babu, S., \& Datta, S. (2015). Revisiting the link between socio-economic development and environmental status indicators-focus on panel data. Environment Development and Sustainability, 17(3), 567-586. https://doi.org/10.1007/s10668-014-9561-6

Becker, W., Saisana, M., Paruolo, P., \& Vandecasteele, I. (2017). Weights and importance in composite indicators: closing the gap. Ecological Indicators, 80, 12-22. https://doi.org/10.1016/j.ecolind.2017.03.056

Boggia, A., \& Cortina, C. (2010). Measuring sustainable development using a multi-criteria model: a case study. Journal of Environmental Management, 91, 2301-2306. https://doi.org/10.1016/j.jenvman.2010.06.009

Boggia, A., Rocchi, L., Paolotti, L., Musotti, F., \& Greco, S. (2014). Assessing rural sustainable development potentialities using a dominance-based rough set approach. Journal of Environmental Management, 144, 160-167. https://doi.org/10.1016/j.jenvman.2014.05.021

Bolcarova, P., \& Kološta, S. (2015). Assessment of sustainable development in the EU 27 using aggregated SD index. Ecological Indicators, 48, 699-705. https://doi.org/10.1016/j.ecolind.2014.09.001

Booysen, F. (2002). An overview and evaluation of composite indices of development. Social Indicators Research, 59, 115-151. https://doi.org/10.1023/A:1016275505152 
Chansarn, S. (2013). Assessing the sustainable development of Thailand. Procedia Environmental Sciences, 17, 611-619. https://doi.org/10.1016/j.proenv.2013.02.077

Chodakowska, E., \& Nazarko, J. (2017). Environmental DEA method for assessing productivity of European countries. Technological and Economic Development of Economy, 23(4), 589-607. https://doi.org/10.3846/20294913.2016.1272069

Chowdhury, S., \& Squire, L. (2006). Setting weights for aggregate indices: an application to the committment to development index and human development index. Journal of Development Studies, 42(5), 761-771. https://doi.org/10.1080/00220380600741904

Compagnolo, L., Carraro, C., Eboli, F., Farnia, L., Parrado, R., \& Pierfederici, R. (2018). The ex-ante evaluation of achieving sustainable development goals. Social Indicators Research, 136, 73-116. https://doi.org/10.1007/s11205-017-1572-x

Čiegis, R., Ramanauskienė, J., \& Šimanskienè, L. (2010). Lietuvos regionu darnaus vystymosi vertinimas. Klaipèdos universiteto leidykla.

Delai, I., \& Takahashi, S. (2011). Sustainability measurement system: a reference model proposal. Social Responsability Journal, 7(3), 438-471. https://doi.org/10.1108/17471111111154563

Gedvilaite, D. (2019). The assessment of sustainable development of a country's regions (Doctoral dissertation). Vilnius Gediminas Technical University, Vilnius, Lithuania. http://dspace.vgtu.lt/handle/1/3797

Ginevičius, R., Gedvilaite, D., \& Bruzgè, Š. (2015). Assessment of a country's regional economic development on the basis of Estimation of a Single Process (ESP) Method. Entrepreneurial Business and Economics Review, 3(2), 141-153. https://doi.org/10.15678/EBER.2015.030210

Ginevičius, R., Gedvilaite, D., Stasiukynas, A., \& Šliogerienè, J. (2018). Quantitative assessment of the dynamic of the economics development of socioeconomic systems based on the MDD method. Inzinerine Ekonomika-Engineering Economics, 29(3), 531-553. https://doi.org/10.5755/j01.ee.29.3.20444

Godlewska-Majkowska, H., Komor, A., \& Typa, M. (2016). Special economic zones as growth and antigrowth poles as exemplified by Polish regions. Entrepreneurial Business and Economics Review, 4(4), 189-212. https://doi.org/10.15678/EBER.2016.040412

Golusin, M., \& Munitlak, O. I. (2009). Definition, characteristics and state of the indicators of sustainable development in countries of Southeastern Europe. Agriculture, Ecosystems and Environment, 130, 67-74. http://doi.org/10.1016/j.agee.2008.11.018

Golusin, M., Munitlak, O. I., \& Teodorovic, N. (2011). The review of the achieved degree of sustainable development in South Eastern Europe - the use of linear regression method. Renewable and sustainable Energic Reviews, 15, 766-772. https://doi.org/10.1016/j.rser.2010.07.064

Graymore, L. M., Sipe, N. G., \& Rickson, R. E. (2010). An index of regional sustainability: A GIS-based multicriteria analysis decision support system for progressing sustainability. Ecological Complexity, 6(4), 453-462. https://doi.org/10.1016/j.ecocom.2009.08.006

Grzebyk, M., \& Stec, M. (2015). Sustainable development in EU countries: concept and rating of levels of development. Sustainable Development, 23(2), 110-123. https://doi.org/10.1002/sd.1577

Halicka, K. (2017). Main concepts of technology analysis in the light of the literature on the subject. Procedia Engineering, 182, 291-298. https://doi.org/10.1016/j.proeng.2017.03.196

Hamilton, C. (2007). Measuring sustainable economic welfare. In G. Atkinson \& S. Dietzm (Eds.), Handbook of sustainable development. Edward Elgar Publishing. https://doi.org/10.4337/9781847205223.00030

He, J., Wan, Y., Feng, L., Ai, J., \& Wang, Y. (2016). An integrated data envelopment analysis and emergybased ecological footprint methodology in evaluating sustainable development, a case study of jiangsu province China. Ecological Indicators, 70, 23-34. https://doi.org/10.1016/j.ecolind.2016.05.042 
Hwang, C.-L., \& Yoon, K. (1981). Multiple attribute decision making: methods and applications a stateof-the-art survey. Springer. https://doi.org/10.1007/978-3-642-48318-9_3

Yeh, L.-T., \& Chang, D.-S. (2020). Using categorical DEA to assess the effect of subsidy policies and technological learning on R\&D efficiency of it industry. Technological and Economic Development of Economy, 26(2), 311-330. https://doi.org/10.3846/tede.2019.11411

Ivanovic, O. D. M., Golusin, M. T., Dpplic, S. N., \& Doolic, T. J. M. (2009). Perspectives of sustainable development in countries of South Eastern Europe. Renewable and Sustainable Energy Reviews, 13(8), 2074-2087. https://doi.org/10.1016/j.rser.2009.03.004

Janker, J., \& Mann, S. (2018). Understanding the social dimension of sustainability in agriculture: a critical review of sustainability assessment tools. Environment, Development and Sustainability, 1-21. https://doi.org/10.1007/s10668-018-0282-0

Kareivaite, R. (2012). Kompleksinis darnaus vystymosi vertinimas taikant daugiakriterius metodus (Doctoral dissertation). Vytautas Magnus University, Kaunas, Lithuania.

https://vb.vdu.lt/permalink/f/grg1fq/ELABAETD2014447

Kondyli, J. (2010). Measurement and evaluation of sustainable development - a composite indicator for the Islands of the North Aeglan region, Greece. Environemental Impact Assessment Review, 30, 347-356. https://doi.org/10.1016/j.eiar.2009.08.006

McLaren, D., Bullock, S., \& Yousef, N. (1998). Tommorow's world: Britain's share in a sustainable future. Earthscan.

Nazarko, J., Ejdys, J., Halicka, K., Nazarko, L., Kononiuk, A., \& Olszewska, A. (2017). Structural analysis as an instrument for identification of critical drivers of technology development. Procedia Engineering, 182, 504-509. https://doi.org/10.1016/j.proeng.2017.03.137

Nazarko, L. (2017). Future-oriented technology assessment. Procedia Engineering, 182, 504-509. https://doi.org/10.1016/j.proeng.2017.03.144

Nazarko, L., \& Melnikas, B. (2019). Operationalising Responsible Research and Innovation - tools for enterprises. Engineering Management in Production and Services, 11(3), 21-28. https://doi.org/10.2478/emj-2019-0017

Parris, T. M., \& Kates, R. W. (2003). Characterizing and measuring sustainable development. Annual Review of Environment and Resources, 28(13), 1-28. https://doi.org/10.1146/annurev.energy.28.050302.105551

Radonovic, M., \& Lior, M. (2017). Sustainable economic-environmental planning in South East Europebeyond-GDP and climate change emphases. Sustainable Development, 25, 580-594.

https://doi.org/10.1002/sd.1679

Rametsteiner, E., Alkan-Olsson, H. P. J., \& Frederiksen, P. (2011). Sustainability indicator developmentscience or political negotiation? Ecological Indicators, 11, 61-70. https://doi.org/10.1016/j.ecolind.2009.06.009

Rees, W. E. (2000). Eco-footprint analysis: merits and brickbats. Ecological Economics, 32(3), 371-374. https://doi.org/10.1016/S0921-8009(99)00157-3

Rogge, N. (2018). Composite indicators as generalizes benefit-of-the-doubt-weighted averages. European Journal of Operational Research, 267(1), 381-392. https://doi.org/10.1016/j.ejor.2017.11.048

Rotmans, J. (2006). Tools for integrated sustainability assessment: a two-track approach. The integrated Assessment Journal, 6(4), 35-57.

Sala, S., Ciuffo, B., \& Nijkamp, P. (2015). A systemic framework for sustainability assessment. Ecological Economics, 114, 314-325. https://doi.org/10.1016/j.ecolecon.2015.09.015

Scherp, J. (1994). What does an economist need to know about the environment? (Directorate-General for Economic and Financial Affairs, Economic papers of the European Commision No. 107). Brussels. 
Schoenoker, N., Hoekstra, R., \& Smits, J. (2015). Comparison of measurement systems for sustainable development at the national level. Sustainable Development, 23, 285-300. https://doi.org/10.1002/sd.1585

Soava, G., Mehedintu, A., \& Sterpu, M. (2020). Relations between income inequality, economic growth and poverty threshold: new evidences from EU countries panels. Technological and Economic Development of Economy, 26(2), 290-310. https://doi.org/10.3846/tede.2019.11335

Spangenberg, J. H. (2002). Institutional sustainability indicators; the analysis of the institutions in Agenda 21 and a draft set of indicators for monitoring their effectivity. Sustainable Development, 10(2), 103-115. https://doi.org/10.1002/sd.184

Statistics Lithuania. (n.d.). https://osp.stat.gov.lt/statistiniu-rodikliu-analize?region=all\#/

Statistics Poland. (n.d.). https://stat.gov.pl/en/

Strezov, V., Evens, A., \& Evans, T. J. (2017). Assessment of the economic, social and environmental dimensions of the indicators for sustainable development. Sustainable Development, 25(3), 242-253. https://doi.org/10.1002/sd.1649

Touceda, M. Y., Neila, F., J., \& Degrez, M. (2018). Modeling socioeconomic pathways to assess sustainability: a tailored development for housing retrofit. The International Journal of Life Cycle Assessment, 23(3), 710-725. https://doi.org/10.1007/s11367-016-1194-6

Turcu, C. (2013). Re-thinking sustainability indicators: local perspectives of urban sustainability. Journal of Environmental Planning and Management, 56(5), 695-719. https://doi.org/10.1080/09640568.2012.698984

Turovets, Y., \& Vishnevskiy, K. (2019). Patterns of digitalisation in machinery-building industries: evidence from Russia. Engineering Management in Production and Services, 11(4), 7-22. https://doi.org/10.2478/emj-2019-0029

Verbunt, P., \& Rogge, N. (2018). Geometric composite indicators with compromise Benefit-of-theDoubt Weights. European Journal of Operational Research, 264, 388-401. https://doi.org/10.1016/j.ejor.2017.06.061

Volkov, A. (2018). Assessment of the impact of the common agricultural policy direct payments system on agricultural sustainability (Doctoral Dissertation). Vilnius Gediminas Technical University, Vilnius, Lithuania.

Wackernagel, M., \& Rees, W. E. (1996). Ecological footprints and appropriated carrying capacity: measuring the natural capital requirements of the human economy. Focus, 6(1).

Wallis, A. M., Graymore, L. M., \& Richards, A. J. (2011). Significance of environment in the assessment of sustainable development: the case of south west Victoria. Ecological Economics, 70(4), 545-605. https://doi.org/10.1016/j.ecolecon.2010.11.010

Wang, J., Wei, X., \& Guo, Q. (2018). A three-dimensional evaluations for regional carrying capacity of ecological environment to social economic development: model development and a case study in China. Ecological Indicators, 89, 348-355. https://doi.org/10.1016/j.ecolind.2018.02.005

Xavier, A., Costa Freitus, M. D. B., Fragoso, R., \& Rosário, M. D. S. (2018). A regional composite indicator for analysing agricultural sustainability in Portugal: a goal programming approach. Ecological Indicators, 89, 84-100. https://doi.org/10.1016/j.ecolind.2018.01.048

Zhou, P., Ang, B. W., \& Zhou, D. Q. (2010). Weighting and aggregation in composite indicator construction: a multiplicative approach. Social Indicators Research, 96(1), 169-181. https://doi.org/10.1007/s11205-009-9472-3

Zinatiradeh, S., Azmi, A., Monavari, S. M., \& Sobhanazdakani, S. (2017). Evaluation and prediction of sustainaility of urban areas: a case study for Kermanshahsity, Iran. Cities, 66, 1-9.

https://doi.org/10.1016/j.cities.2017.03.002 